\title{
Analysis of soil contamination with heavy metals in (the three) highly contaminated industrial zones
}

\author{
Oqil Rasulov ${ }^{1}$ - Marián Schwarz ${ }^{2} \cdot$ Adrienn Horváth $^{3} \cdot$ Firuz Zoirov $^{1} \cdot$ Nuridini Fayz $^{1}$
}

Received: 27 December 2019 / Accepted: 31 October 2020 / Published online: 19 November 2020

(c) Springer Nature Switzerland AG 2020

\begin{abstract}
Soils of industrial regions are more sensitive to transfer and accumulate anthropogenic pollution, especially in the case of a Havaria. The environmental effects of three aluminium plants-a working plant (Tajikistan), a storage plant (Slovakia) and a Havaria-affected plant (Hungary)—were examined by the determination of the contamination levels. In addition, the research focus was on to identify and compare the topsoil chemical properties near the aluminium plants and to assess the effects of the red mud accident in Hungary (Ajka), by analysing contaminated soil in this particular area. Using X-ray fluorescence (XRF) spectroscopy analysis, amount of 9 toxic metals in the shallow topsoil $(0-20,20-40 \mathrm{~cm})$ from industrial areas were measured. Considering all of the studied areas around aluminium plants, extreme concentrations of Cd $\left(1591.20 \mathrm{mg} \mathrm{kg}^{-1}\right), \mathrm{Pb}\left(2514 \mathrm{mg} \mathrm{kg}^{-1}\right), \mathrm{Cu}\left(1362.67 \mathrm{mg} \mathrm{kg}^{-1}\right), \mathrm{Zn}\left(1476.02 \mathrm{mg} \mathrm{kg}^{-1}\right), \mathrm{Ni}\left(1142.95 \mathrm{mg} \mathrm{kg}^{-1}\right)$, $\mathrm{Co}\left(1295.81 \mathrm{mg} \mathrm{kg}^{-1}\right), \mathrm{Cr}\left(1379.69 \mathrm{mg} \mathrm{kg}^{-1}\right)$, Fe $\left(24,861.73 \mathrm{mg} \mathrm{kg}^{-1}\right)$, and $\mathrm{Al}\left(18,221.60 \mathrm{mg} \mathrm{kg}^{-1}\right)$ were still recorded in Hungary, and the lowest concentrations were found in Žiar nad Hronom (Slovakia). Results showed that the concentration of heavy metals is significant in all investigated areas, even up to 5 years after the accident in Hungary. This level of soil contamination is able to damage plants and trees which consequently can lead to soil erosion and deforestation.
\end{abstract}

Keywords Aluminium industry $\cdot$ Heavy metals $\cdot$ Soil contamination $\cdot$ Red mud

\section{Introduction}

During the last few decades, the heavy metal concentration in some soils has increased due to heavy industrialisation [1]. Any metals, either naturally occurring or of artificial origin, can be considered pollutants when they are found in increased concentration in the wrong place. Human activities often lead to redistribution of heavy metals in a way that can cause adverse effects. Certain metals accumulate in soil in concentrations that are toxic to plant life, which may subsequently pose a health hazard to domestic animals and humans. Accumulations of these metals in the soil are due to several factors, such as discharges from smelters, metal-based industries, chemical manufacturing, industry, and abandoned mining sites [2].

The global inventory of red mud continued to raise the total amount of red mud stored in land in 2008 estimated to be over 2.7 billion tons [3]. Nevertheless, an annual growth rate of the red mud is estimated approximately 120 million tons worldwide [4]. About 50 million tons of red mud is stored in Hungary [5] in land-based disposal pits. Therefore, there was a risk of this huge amount of the storage that can lead to environmental disaster that happened. Last time, a mining village with $\sim 900$ ha of natural vegetation destroyed, when the dam wall of an iron mine

Oqil Rasulov, oqil.rasulov@gmail.com; Marián Schwarz, schwarz@tuzvo.sk; Adrienn Horváth, hadri@emk.nyme.hu| ${ }^{1}$ Faculty of Innovative Technologies, Department of Life Safety and Ecology, Tajik Technical University named after academician M.S. Osimi, Academic Rajabovho 10, 734042 Dushanbe, Tajikistan. ${ }^{2}$ Faculty of Ecology and Environmental Sciences, Department of Environmental Engineering, Technical University in Zvolen, T. G. Masaryka 24, 96053 Zvolen, Slovakia. ${ }^{3}$ Faculty of Forestry, Department of Soil Site Survey, University of West Hungary, 4. Bajcsy-Zsilinszky, Sopron 9400, Hungary. 
collapsed near to Brazilian costs and poisoned the complete aquatic ecosystem [6]. In most cases, open-air reservoirs keeping the mixture of sodium hydroxide and toxic metals (e.g. $\mathrm{Cd}, \mathrm{Cr}, \mathrm{Hg}, \mathrm{As}, \mathrm{Ni}$ ) in large amount on extreme alkaline media [7]. Copper ( $\mathrm{Cu}$ ) and zinc ( $\mathrm{Zn})$ are essential for metabolic processes by the organisms over time, but mercury $(\mathrm{Hg})$, chromium $(\mathrm{Cr})$, and cadmium $(\mathrm{Cd})$ have an unknown role in biological systems [8]. Toxic trace metals easily bind and accumulate between $\mathrm{pH} 8-14$, but $\mathrm{pH}$ decrease strongly influences their speciation and hence bioavailability (Urushadze, 2007). Toxic heavy metals are not biodegradable, and their structure persists against the effects of environmental disassembly for a long time $[9,10]$. Once heavy metals accumulate in soil, they can gradually advance to roots and spread to stems, leaves, and other constituent parts of plants, which can consequently lead to damage to the lipid structures of plasma membranes [11]. Aluminium production is one of the most widely used processing technology that has a high environmental impact due to the high risk of bauxite mining, transport of raw materials and processing that endangers human health, as well as the storage of residual red mud. To store waste sludge is always a risk factor.

Current research presents the comparison of environmental risk of heavy metal accumulation in soils collected around three aluminium plants, which are in different condition. A processing one (Tajikistan), a closed one (Slovakia) and a Havaria-affected (Hungary) industrial region in three different countries were involved to evaluate the environment condition and provide recommendations for the further soil management. With the detection of toxic metal enrichment in the topsoil (EF), pollution levels were determined to evaluate the environmental impacts of aluminium production.

\section{Materials and Methods}

The three selected study areas are located in highly used industrial region in Tajikistan, in Slovakia, and in Hungary. At Tursunzoda in Tajikistan, Žiar nad Hronom in Slovakia, and Ajka in Hungary, aluminium plants TALCO (Tajik Aluminium Company), SLOVALCO (Slovak Aluminium Company), and MAL (Hungarian Aluminium Company) are situated. At TALCO, alumina is imported from abroad, but in the near future the commencement of alumina production from its own raw materials is planned. At SLOVALCO, alumina production ended in 1992 . For 40 years of its production in Slovakia, more than 10 million tons of brown and red mud was accumulated and ended up at a pond near the aluminium smelter. Reclamation of this pond was completed in 2013 at a cost of more than 53 million euros, and currently the tailing pond is well preserved. In MAL, alumina was produced from the start of Al production by the wet Bayer process to produce much larger amount of red mud, which is deposited in the pond near the aluminium smelter, and this was the cause of a severe accident when the dam broke in 2010.

Soil samples were collected on several sites at the surroundings of the aluminium plants in Hungary, Slovakia, and Tajikistan as well. Altogether 10 samples were taken from Slovakia and Tajikistan, and 11 soil samples were taken from Hungary. The distance to the farthest point was $12.5 \mathrm{~km}$ from the pollution source. The sampling sites had different land use (agricultural area, grassland, river bank, forest) profiles that are shown in Figs. 1, 2, and 3.

TALCO (Tajik Aluminium Company) is located on the western border of country, near to Republic of Uzbekistan. This plant is still operating and produces more than 100,000 tons of aluminium/year since Tajikistan has no native aluminium ore, so the raw material has to be imported. Agricultural zones and grasslands surround the area of the facility; therefore, TALCO regularly operating monitoring measurements around plant and previous study showed that presents of fluoride accumulation in vegetables ranged $0.02-3.91 \mathrm{mg} \mathrm{kg}^{-1}$ and high concentration was found in leafy vegetables [12].

The Slovak aluminium company (SLOVALCO) is located in the middle of the country near to Žiar nad Hronom. The aluminium plants initially used Söderberg technology, until effective filters were installed. In 1996 the Söderberg technology was replaced by the new Prebake technology [13]. The facility surrounded by forests on southern side; therefore, it is favourable that the northwestern winds transport the air pollutant in the direction of this "natural filter" mostly not into the city.

The most polluted study site is the Hungarian region where a red mud disaster in Ajka (Hungary) occurred on October 4, 2010. The year 2010 was the wettest year in the decade ( 1200 to $1400 \mathrm{~mm}$ ) on this region. The saturated content of the opened smelter and human negligence led to a flood of toxic sludge flowed onto unprotected soil, including three settlements [14] and a river meadow. Due to the wet conditions, the water-saturated soil prevented the infiltration of the contamination into deeper soil layers [15], but it was able to cover larger area. After 10 years, the regeneration of the edaphone is still in progress $[7,16]$. The study area consists of agricultural zones, grasslands, riverbank points and forest site. Bauxite ores worked near to the plant, therefore the transport of red dust is characteristic not only originate from the opened red mud reservoir but also from opened mining areas by the wind.

Soil sample collection was carried out in 2015 (Hungary and Tajikistan) and 2016 (Slovakia) after the vegetation period. Topsoil samples were taken from 0 to 20 and $20-40 \mathrm{~cm}$ depth from each plots. A probe tool was 


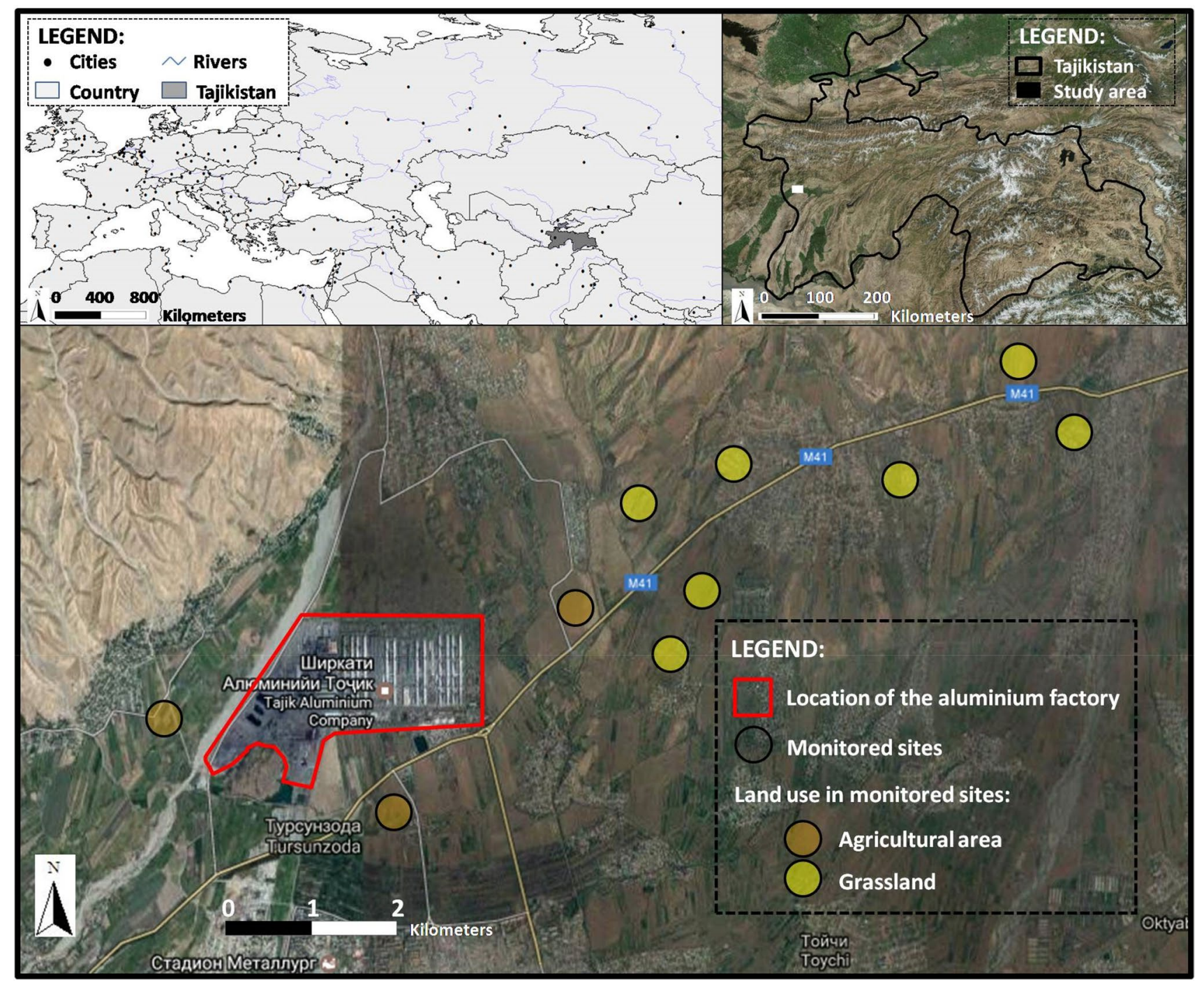

Fig. 1 Investigated area around TALCO in Tursunzoda, Tajikistan. URL: https://www.google.com/maps/place/Tursunzoda ,+Tad\%C5\%BEikistan/@38.5439327,68.2361244,4942m/data $=! 3 \mathrm{~m} 1$ ! 1 e3! $4 \mathrm{~m} 12$ ! $1 \mathrm{~m} 6 ! 3 \mathrm{~m} 5$ ! $1 \mathrm{~s} 0 \times 38 \mathrm{~b} 5 \mathrm{ab} 493 \mathrm{bd} 1296 \mathrm{~d}: 0 \times 97 \mathrm{~b}$

used to collect samples uniformly across the whole plot. The samples were analysed in soil laboratory. During the preparation, the soil had been air-dried $\left(20-40^{\circ} \mathrm{C}\right)$ and homogenised. A 2-mm metallic sieve was used to separate the skeletal percent. Pellets with smooth surface and equal density were prepared from each soil sample. The loose powdered samples $(75 \mu \mathrm{m})$ were reduced by milling about $60 \mu \mathrm{m}$ or less. The sample and binding material having a total mass of $4.9 \mathrm{~g}$ was dropped into screw-top grinding jars during the milling and mixture using the RETSCH Mixer Mills (MM 301). SPECAC hydraulic press (max. limit: 15,000 kg) formed pellets $(\varnothing=32 \mathrm{~mm}, \delta=3 \mathrm{~mm})$, which are necessary to carry out an XRF sample cup for analysis. This method is based
$687477 f$ c3f203!2sTajik+Aluminium+Company! $8 \mathrm{~m} 2$ !3d38.54437 26 ! $4 \mathrm{~d} 68.2236287$ !3m4!1s0x38b5ab716f3f368f:0xbc3cb0d91f22d $\mathrm{e} 83 ! 8 \mathrm{~m} 2 ! 3 \mathrm{~d} 38.5301102 ! 4 \mathrm{~d} 68.2146853$ (16.5.2017)

on the theoretical background of X-ray fluorescence spectroscopy.

The extent of soil contamination was assessed using enrichment factor (EF). EF is a good tool to determine whether a metal source is anthropogenic or naturally occurring. For calculating the EF, the following equation was used:

$\mathrm{EF}=\frac{\left.\frac{x}{\mathrm{Al}} \text { (sediment }\right)}{\frac{X}{\mathrm{Al}}(\text { crust })}$

where $\frac{X}{A l}$ is the ratio of the heavy metal $(X)$ to the Al. 


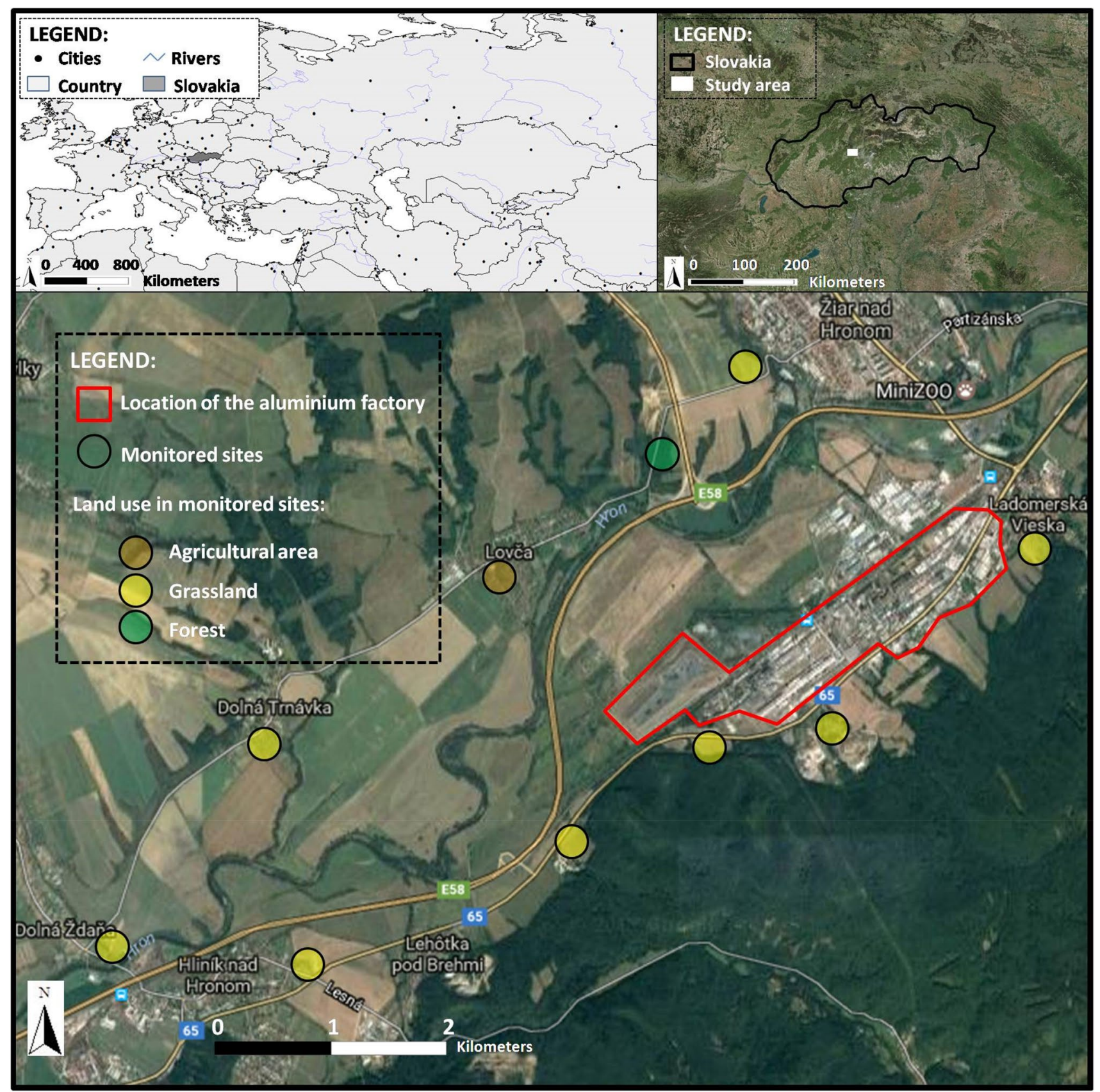

Fig. 2 Investigated area around SLOVALCO in Žiar nad Hronom, Slovakia. URL: https://www.google.com/maps/place /965+01+\%C5\%BDiar+nad+Hronom,+Slovensko/@48.57414
$26,18.8356149,8361 \mathrm{~m} /$ data $=! 3 \mathrm{~m} 1 ! 1 \mathrm{e} 3 ! 4 \mathrm{~m} 5 ! 3 \mathrm{~m} 4 ! 1 \mathrm{~s} 0 \times 47152 \mathrm{e} 5312 \mathrm{c}$ 02675:0x400f7d1 c6972bb0!8m2!3d48.5905012!4d18.8548946 (16.5.2017)
EF values were interpreted as suggested by Birth [17] for metals studied with respect to the crust average [18]. $\mathrm{EF}<1$ indicates no enrichment, $\mathrm{EF}<3$ is minor enrichment, $E F=3-5$ is moderate enrichment, $E F=5-10$ is moderately severe enrichment, $\mathrm{EF}=10-25$ is severe enrichment, $E F=25-50$ is very severe enrichment, and $\mathrm{EF}>50$ is extremely severe enrichment.

The statistical processing of the results was carried out using STATISTICA 10 (ANOVA) to test differences between two or more means and R. Pearson correlation was used to determine whether there was a common source and relationship between the trace metals. 


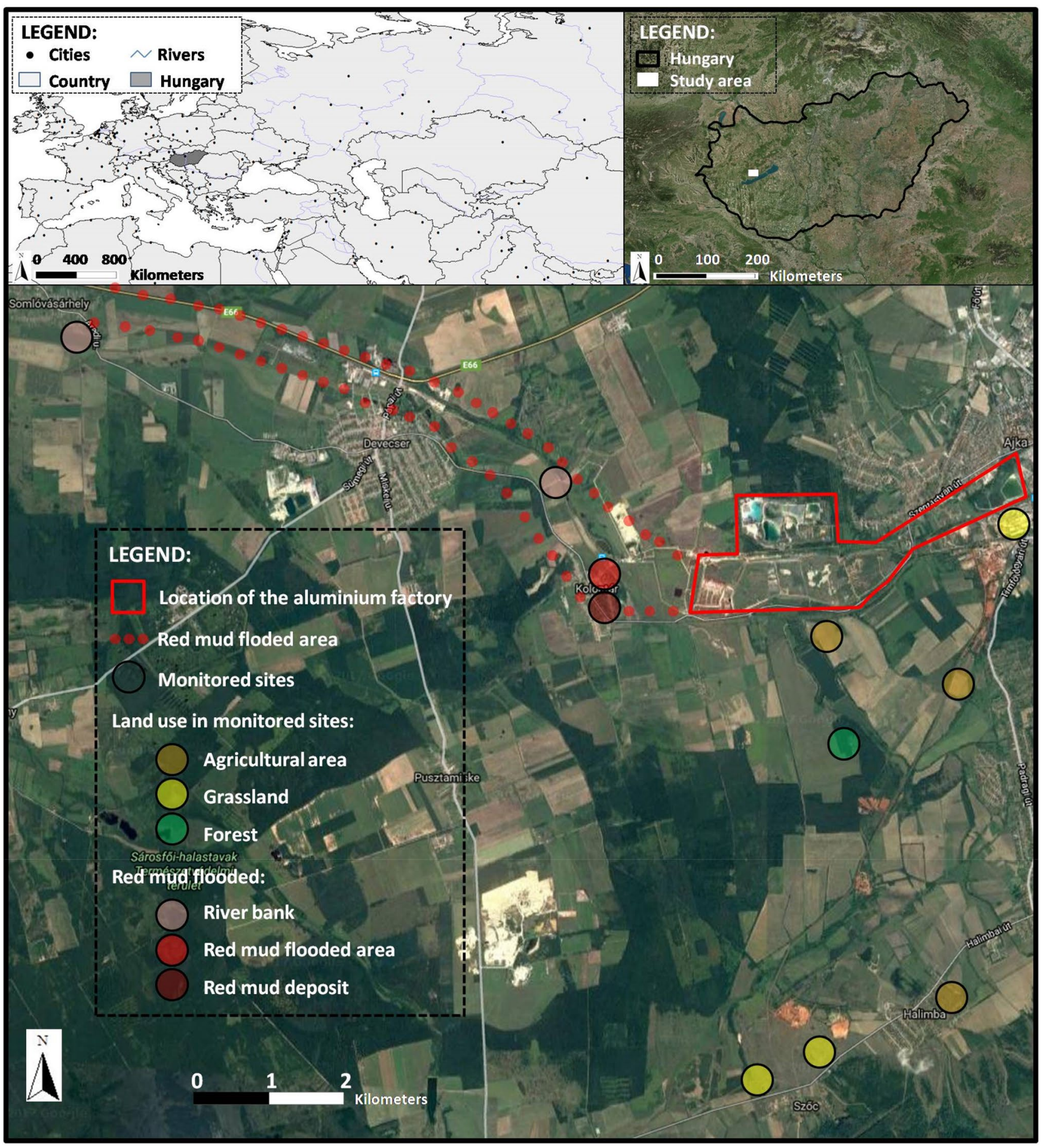

Fig. 3 Location of studied area and the territory of the red mud disaster (Ajka, Hungary). URL: https://www.google.com/maps/ place/Ajka,+Ma\%C4\%8Farsko/@47.0870216,17.4156361,17208

\section{Results and Discussion}

Lithogenic (geogenic) origin of toxic metals is characteristic for mineral soils due to geological conditions. Pedogenic contamination from human impacts mostly has an $\mathrm{m} /$ data $=! 3 \mathrm{~m} 1 ! 1 \mathrm{e} 3 ! 4 \mathrm{~m} 5 ! 3 \mathrm{~m} 4$ ! $1 \mathrm{~s} 0 \times 47697390 \mathrm{f} 44 \mathrm{f} 1079: 0 \times 400 \mathrm{c} 4290$ c1e1750!8m2!3d47.1036349!4d17.5517783 (16.5.2017)

effect on natural element content, which has to be considered in the reliability of the evaluation. The mobility of heavy metals depends on soil $\mathrm{pH}$. The amount of $\mathrm{pH}$ was $6.5-8.2$ in all study plots, which means that the toxic element mobility is low. Most of the elements mobilised 
at an acidic $\mathrm{pH}$ (5-6); therefore for neutral or alkaline elements, low accumulations were characteristic of the investigated soils.

Table 1 shows the mean value, standard deviation (SD), standard errors (Std. Err), threshold limit value (TLV), enrichment factors (EF), and minimum and maximum concentrations of heavy metals $(\mathrm{Cd}, \mathrm{Pb}, \mathrm{Zn}, \mathrm{Cu}, \mathrm{Ni}$, $\mathrm{Co}, \mathrm{Fe}, \mathrm{Cr}$, and $\mathrm{Al}$ ) in the soils of all studied areas in Tajikistan, Slovakia, and Hungary.
By the amount of total toxic metal accumulation in samples, the following order could be presented: $\mathrm{Al}>$ $\mathrm{Fe}>\mathrm{Co}>\mathrm{Cr}>\mathrm{Ni}>\mathrm{Zn}>\mathrm{Cu}>\mathrm{Pb}>\mathrm{Cd}$ around TALCO, $\mathrm{Fe}>$ $\mathrm{Al}>\mathrm{Zn}>\mathrm{Co}>\mathrm{Cr}>\mathrm{Pb}>\mathrm{Ni}>\mathrm{Cu}>\mathrm{Cd}$ around SLOVALCO, and $\mathrm{Fe}>\mathrm{Al}>\mathrm{Pb}>\mathrm{Cd}>\mathrm{Zn}>\mathrm{Cr}>\mathrm{Cu}>\mathrm{Co}>\mathrm{Ni}$ around MAL. Table 1 shows that the levels of $\mathrm{Pb}$ in Ajka and Žiar nad Hronom exceeded the TLV. $\mathrm{Pb}$ is very mobile and readily acceptable by plants, as are $\mathrm{Zn}, \mathrm{Cd}, \mathrm{Ni}, \mathrm{Cr}$, and $\mathrm{Co}$, even when the concentrations of these toxic metals are close to the natural background limits. The concentrations of

Table 1 Summary results of descriptive statistical analysis of selected heavy metal concentrations, compared with their TLV and EF [ $n=20]$

\begin{tabular}{|c|c|c|c|c|c|c|c|}
\hline Heavy metals & Min. $\left(\mathrm{mg} \mathrm{kg}^{-1}\right)$ & $\operatorname{Max} .\left(\mathrm{mg} \mathrm{kg}^{-1}\right)$ & $\mathrm{SD}(\sigma)$ & Std. err. & $\begin{array}{l}\text { Mean value } \\
\left(\mathrm{mg} \mathrm{kg}^{-1}\right)\end{array}$ & $\operatorname{TLV}^{\mathrm{a}}\left(\mathrm{mg} \mathrm{kg}^{-1}\right)$ & Ranges of EF \\
\hline \multicolumn{8}{|l|}{$T A L C O^{\mathrm{b}}$} \\
\hline $\mathrm{Cd}$ & 20.22 & 28.54 & 2.011 & 0.44 & 22.89 & $1^{c}$ & $11.7-296.4$ \\
\hline $\mathrm{Pb}$ & 8.13 & 28.68 & 1.472 & 0.32 & 16.36 & $30^{c}$ & $0.1-3.3$ \\
\hline $\mathrm{Zn}$ & 34.14 & 89.25 & 15.095 & 3.31 & 51.74 & $110^{c}$ & $0-1.2$ \\
\hline $\mathrm{Cu}$ & 44.15 & 56.24 & 3.260 & 0.72 & 48.06 & $33^{c}$ & $0.1-2.4$ \\
\hline $\mathrm{Ni}$ & 106.08 & 166.99 & 13.627 & 3.04 & 115.8 & $40^{c}$ & $0.2-4$ \\
\hline Co & 89.86 & 243.29 & 54.031 & 6.93 & 217.1 & $5^{c}$ & $0.3-21.9$ \\
\hline $\mathrm{Fe}$ & 465.3 & 32,992 & 7720 & 1452 & 24,355 & - & - \\
\hline $\mathrm{Cr}$ & 92.08 & 183.46 & 20.24 & 4.52 & 136.16 & $6^{c}$ & $0.2-3$ \\
\hline $\mathrm{Al}$ & 3536 & 100,351 & 24,785 & 4592 & 14,023 & - & - \\
\hline \multicolumn{8}{|l|}{ SLOVALCO } \\
\hline $\mathrm{Cd}$ & 18.68 & 21.63 & 0.720 & 0.16 & 20.21 & $0.4^{d}$ & $55.7-92.5$ \\
\hline $\mathrm{Pb}$ & 16.42 & 173.34 & 0.659 & 0.15 & 45.36 & $25^{d}$ & $0.9-9.5$ \\
\hline $\mathrm{Zn}$ & 35.75 & 232.06 & 55.12 & 12.41 & 86.33 & $100^{d}$ & $0.4-1.8$ \\
\hline $\mathrm{Cu}$ & 24.2 & 49.16 & 5.853 & 1.34 & 40.86 & $30^{d}$ & $0.2-0.7$ \\
\hline $\mathrm{Ni}$ & 97.75 & 110.55 & 13.627 & 0.65 & 101.53 & $40^{d}$ & $0.7-1.3$ \\
\hline Co & 156.8 & 216.68 & 31.02 & 3.49 & 193.17 & $15^{d}$ & $4.4-7.6$ \\
\hline $\mathrm{Fe}$ & 13,660 & 28,704 & 6495 & 901.4 & 21,285 & $400^{d}$ & - \\
\hline $\mathrm{Cr}$ & 76.57 & 179.44 & 27.07 & 6.10 & 117.44 & $100^{d}$ & $0.6-1.5$ \\
\hline $\mathrm{Al}$ & 9011 & 15,203 & 1606 & 363.6 & 11,692 & - & - \\
\hline \multicolumn{8}{|l|}{$M A L^{\mathrm{b}}$} \\
\hline $\mathrm{Cd}$ & 0.06 & 159.120 & 294.77 & 54.73 & 59.54 & $1^{\mathrm{e}}$ & $0.45-3593.4$ \\
\hline $\mathrm{Pb}$ & 1.14 & 251.4 & 463.64 & 86.09 & 105.25 & $100^{e}$ & $0.98-90.84$ \\
\hline $\mathrm{Zn}$ & 19.76 & 147.602 & 268.53 & 49.86 & 114.30 & $200^{e}$ & $0.44-32.36$ \\
\hline $\mathrm{Cu}$ & 4.93 & 136.267 & 259.65 & 48.21 & 78.70 & $75^{e}$ & $0.18-11.19$ \\
\hline $\mathrm{Ni}$ & 1.28 & 114.295 & 209.92 & 38.98 & 53.53 & $40^{e}$ & $0.12-6.88$ \\
\hline Co & 0.008 & 129.581 & 239.16 & 44.41 & 54.21 & $30^{e}$ & $0.01-23.41$ \\
\hline $\mathrm{Fe}$ & 234.85 & $24,861.73$ & 5066.1 & 940.76 & 7713.57 & - & - \\
\hline $\mathrm{Cr}$ & 0.40 & 137.969 & 251.94 & 46.78 & 74.66 & $1^{e}$ & $0.20-6.23$ \\
\hline $\mathrm{Al}$ & 6082 & $18,221.60$ & 3681.6 & 683.67 & 6082.65 & - & - \\
\hline
\end{tabular}

Min. minimum concentration value, Max. maximum concentration value, TLV threshold limit value, SD standard deviation, Std. err. standard error, EF enrichment factor

${ }^{a}$ Threshold limit value according to legislations of separate countries

${ }^{\mathrm{b}}$ Aluminium plants

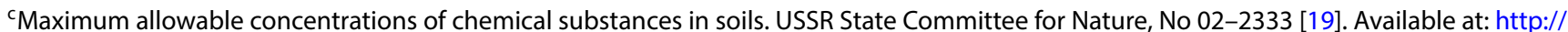
www.gidrogel.ru/ecol/hv_met.htm\#table2

dSlovakia Act. No. 59 [20] as amended

e Joint Decree. no.10/2000 (VI.2) [21]

SN Applied Sciences 
$\mathrm{Cd}, \mathrm{Ni}, \mathrm{Co}$, and $\mathrm{Cr}$ found in the studied areas of Slovakia and Tajikistan were at a level higher than the TLV, but in Hungary all metals were found in concentrations higher than the TLV. However, the TLV is different in each country (Table 1). For instance, the maximum concentration of $\mathrm{Zn}$ in Tajikistan was $89.25 \mathrm{mg} \mathrm{kg}^{-1}$, where the TLV is $110 \mathrm{mg} \mathrm{Zn} \mathrm{kg}^{-1}$; in Žiar nad Hronom (Slovakia) $232.06 \mathrm{mg} \mathrm{Zn} \mathrm{kg}^{-1}$ was found, and the TLV is $100 \mathrm{mg} \mathrm{Zn} \mathrm{kg}^{-1}$. Illustration of heavy metals distribution in all studies area is shown in Figs. 4, 5, 6, 7, 8, and 9. A comparison of statistical indicators between SLOVALCO and TALCO is shown in Fig. 10. Heavy metals in Hungary can be seen in Fig. 11.

High EF values for $\mathrm{Cd}$, $\mathrm{Co}$, and $\mathrm{Pb}$ in Tajikistan; $\mathrm{Cd}, \mathrm{Pb}$, and Co in Slovakia; and extremely high EF values in Hungary were found in soil samples, which received a huge amount of metallic discharge, mainly from aluminium plants. The EF values for $\mathrm{Cd}$ were extremely high, which indicates a high degree of $\mathrm{Cd}$ contamination. Co had the second highest EF values (in the case of Slovakia and Tajikistan) (Table 1) among the metals studied. $\mathrm{Zn}, \mathrm{Cu}$, and $\mathrm{Cr}$ exhibited the lowest EF values among the metals studied in both countries (Slovakia and Tajikistan).

When comparing the results of this study obtained in Hungary to the official measurement data, which were made one day after the disaster by the Hungarian Academy of Science-Institute of Materials and Environmental Chemistry-Chemical Research Centre (HAS-IMEC-CRC), by Bálint Analytic (accredited analytic laboratory-NAT 1-1666/2011), and by the Geological and Geophysical Institute of Hungary (GGIH), it should be noted that the data obtained during this study are much smaller concentrations.

For instance, the measurement taken in 05.10 .2010 by HAS-IMEC-CRC, within $1 \mathrm{~km}$ of the west side of Kolontar revealed the following concentrations: $632-677 \mathrm{mg} \mathrm{kg}^{-1}$ for $\mathrm{Cr}, 192-219 \mathrm{mg} \mathrm{kg}^{-1}$ for $\mathrm{Ni}, 189-195 \mathrm{mg} \mathrm{kg}^{-1}$ for $\mathrm{Pb}$, and $47.9-56.7 \mathrm{mg} \mathrm{kg}^{-1}$ for $\mathrm{Zn}$. However, the sample from this study which was collected on 04.24.2015 in a location $1 \mathrm{~km}$ from the location of the dam failure, East-Kolontar (RMF1), showed the following values: $0.20 \mathrm{mg} \mathrm{kg}^{-1}$ for $\mathrm{Cd}, 27.12 \mathrm{mg} \mathrm{kg}^{-1}$ for $\mathrm{Cr}, 10.81 \mathrm{mg} \mathrm{kg}^{-1}$

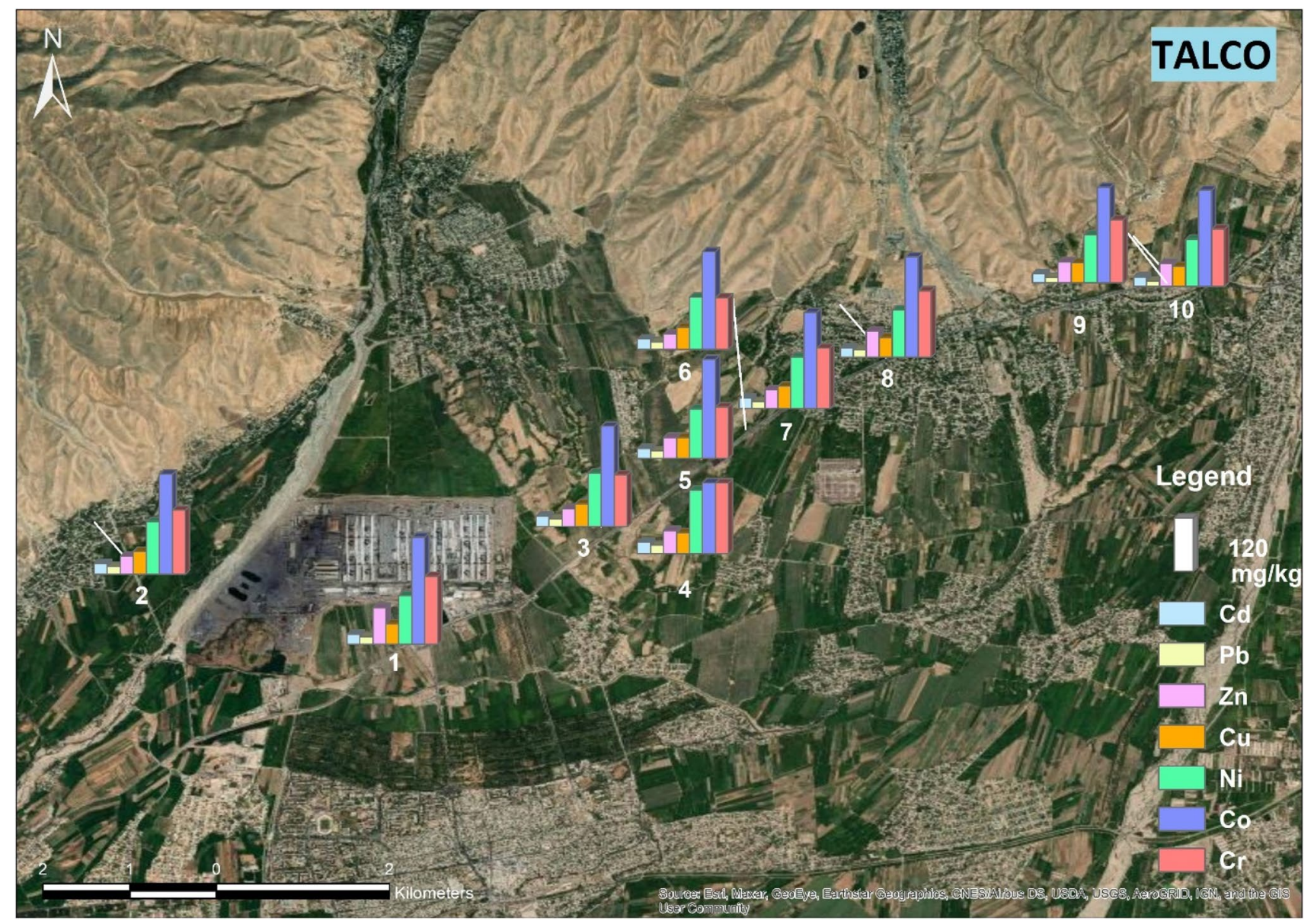

Fig. 4 Distribution of heavy metals around TALCO (Tajikistan) 


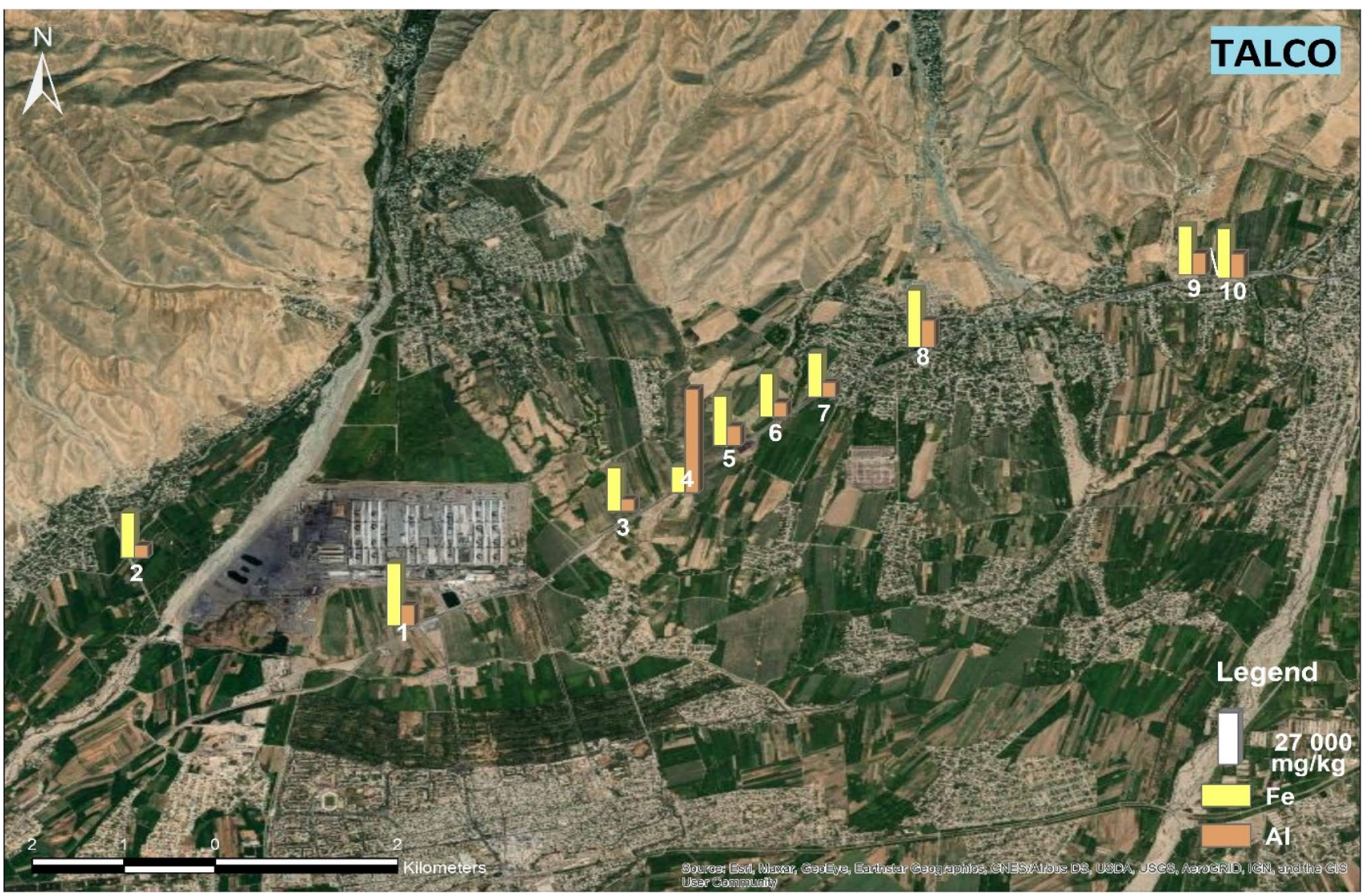

Fig. 5 Distribution of Al and Fe around TALCO (Tajikistan)

for $\mathrm{Ni}, 14.49 \mathrm{mg} \mathrm{kg}^{-1}$ for $\mathrm{Pb}$, and $37.71 \mathrm{mg} \mathrm{kg}^{-1}$ for $\mathrm{Zn}$ (soil samples from 0 to $20 \mathrm{~cm}$ depth).

Although these samples contained low concentrations of trace metals, some samples showed higher contents. For example, a red mud sample in solid form, which was found on the soil surface, showed higher total metal concentrations $\left(1379.69 \mathrm{mg} \mathrm{kg}^{-1}\right.$ for $\mathrm{Cr}$, $1142.95 \mathrm{mg} \mathrm{kg}^{-1}$ for $\mathrm{Ni}, 2514.1 \mathrm{mg} \mathrm{kg}^{-1}$ for $\mathrm{Pb}$, and $1476.0 \mathrm{mg} \mathrm{kg}^{-1}$ for $\mathrm{Zn}$ ) than found in previous studies mentioned above.

From Fig. 11, it can be seen that the obtained data were not symmetric. This may be due to the soil contamination; however, the studied area included both contaminated (by red mud) and non-contaminated lands.

The total metal content was higher in the plots formerly affected by the red mud flood. Results showed the highest total metal concentrations in red mud (e.g. $1591.20 \mathrm{mg} \mathrm{kg}^{-1} ; \mathrm{EF}=2550$ ).

The concentrations of trace metals recorded around all of the aluminium plants showed values that were above the recommended limit set for trace metals in soils ([19, 20] as amended; Joint Decree. No.10/2000 (VI.2), KöMEüM-FVM-KHVM). Moreover, the results of this study are in agreement with other studies, where soils that were collected around aluminium plants exhibited values that were above the WHO recommended limits [22].

In addition, the correlation between elements was calculated to identify their connection and the sources of polluters in the studied areas. The results of the output correlation matrix can be seen in Figs. 12, 13, and 14. Correlations between metals were very weak in Tajikistan and Slovakia, but some positive correlations were noted for some of the trace metals, such as $\mathrm{Cd}, \mathrm{Pb}$, and $\mathrm{Zn}$, in these studied areas.

A higher concentration of trace metals was recorded around TALCO than SLOVALCO. This high heavy metal content is probably due to atmospheric deposition and other factors such as geographical location and climate, as well as the capacity of the plant. Moreover, this is the first time that this kind of research has been conducted in this area (in Tajikistan) and the authors are not in possession of all of the information regarding the past management of these soils and the related heavy metal input; therefore, this study suggests more investigation in this area is required. Concentrations of heavy metals in soil samples around SLOVALCO are found to be higher than background values. For example, background values in A-horizons of Slovakia soil samples are: $0.3 \mathrm{mg} \mathrm{kg}^{-1}$ for $\mathrm{Cd}, 20 \mathrm{mg} \mathrm{kg}^{-1}$ for 


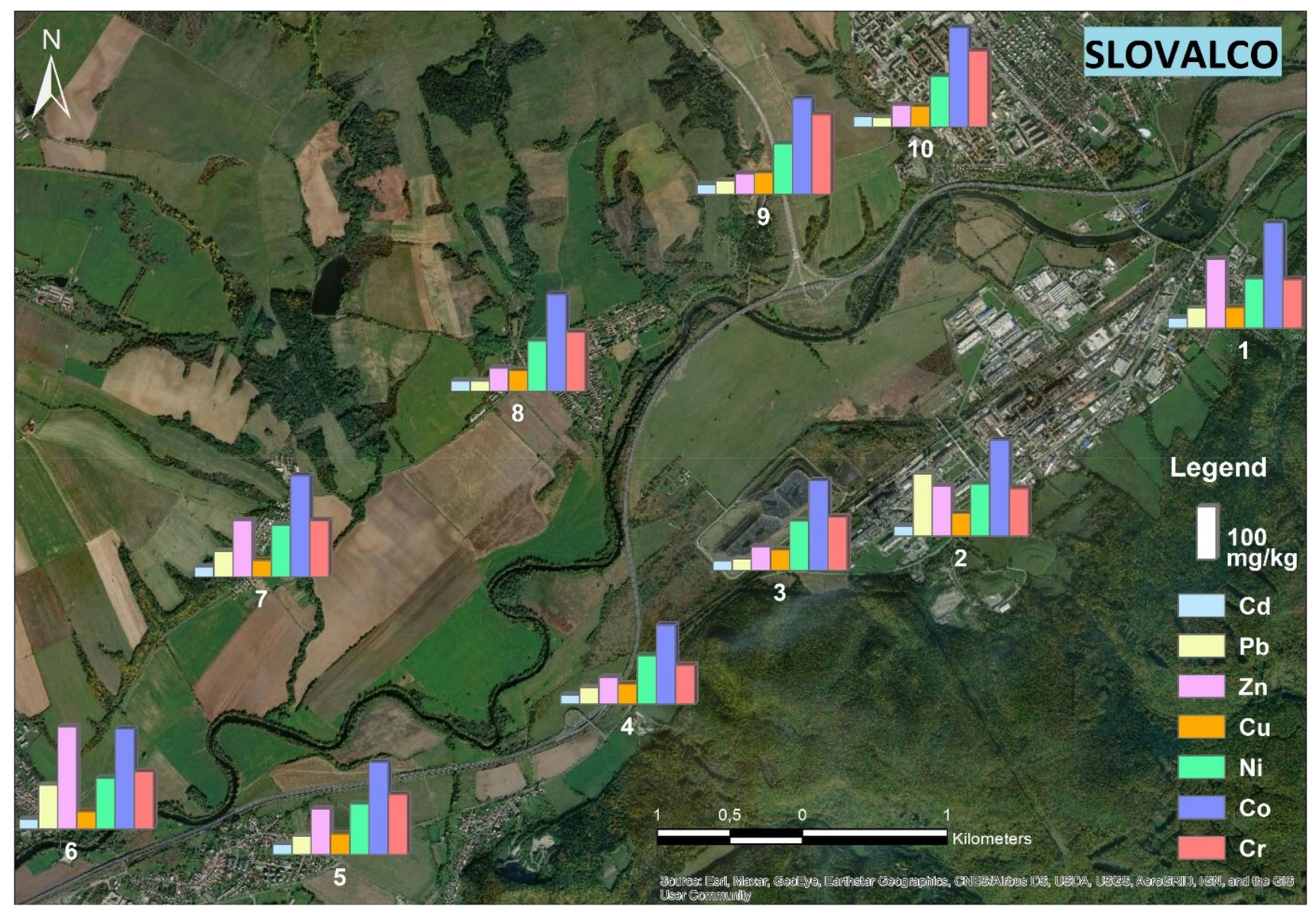

Fig. 6 Distribution of heavy metals around SLOVALCO (Slovakia)

$\mathrm{Pb}, 61 \mathrm{mg} \mathrm{kg}^{-1} \mathrm{Zn}, 17 \mathrm{mg} \mathrm{kg}^{-1}$ for $\mathrm{Cu}, 21 \mathrm{mg} \mathrm{kg}^{-1}$ for $\mathrm{Ni}$, $9 \mathrm{mg} \mathrm{kg}^{-1}$ for Co and $85 \mathrm{mg} \mathrm{kg}^{-1}$ for $\mathrm{Cr}$ [23]. All soil samples collected around TALCO and SLOVALCO were very close to roads. Moreover, concentrations of trace metals from the soil around the aluminium plants in the present study may be linked to the number of years for which the factory has been operational.

From Fig. 14, it can be seen that a strong positive correlation was found between many trace elements. This suggests that these trace metals are pollutants from the same source, such as the aluminium plants or from vehicle emissions. However, in the case of Hungary, the main source of soil contamination is thought to be the red mud. Even though the investigation was conducted five years after the accident, the results obtained suggest that the levels of heavy metals are still significant.

Considering all of the heavy metals that were analysed from all of the study areas around Žiar nad Hronom (Slovakia), Ajka (Hungary), and Tursunzoda (Tajikistan), the highest concentrations of $\mathrm{Cd}, \mathrm{Cu}, \mathrm{Zn}, \mathrm{Ni}, \mathrm{Co}, \mathrm{Cr}, \mathrm{Fe}$, and $\mathrm{Al}$ were recorded in $\mathrm{Ajka}$, and the lowest in Žiar nad Hronom. Therefore, for all of the heavy metals investigated in this study, the most polluted areas can be shown in the order of Ajka > Tursunzoda > Žiar nad Hronom.

Based on data, industrial activities may cause moderate toxic element accumulation in soils. Regarding the order of magnitude of the levels of $\mathrm{Cd}, \mathrm{Cu}, \mathrm{Zn}, \mathrm{Ni}, \mathrm{Co}, \mathrm{Cr}, \mathrm{Fe}$, and $\mathrm{Al}$, there were no significant differences between the two layers. Based on result, it cannot be clearly confirmed that the upper layer is more polluted than the lower layer. Mostly in $0-20 \mathrm{~cm}$ depth, several samples contained extreme heavy metal contents which exceeded the allowed pollution limits, but toxic metals accumulate outstanding element content in such case as well.

\section{Conclusions}

The results of the present investigation revealed that the concentration of heavy metals is significant in all of the investigated areas, exceeding the threshold limit values. These anomalous concentrations are a result of anthropogenic activities, mostly aluminium production and waste disposal. However, high concentrations of heavy 


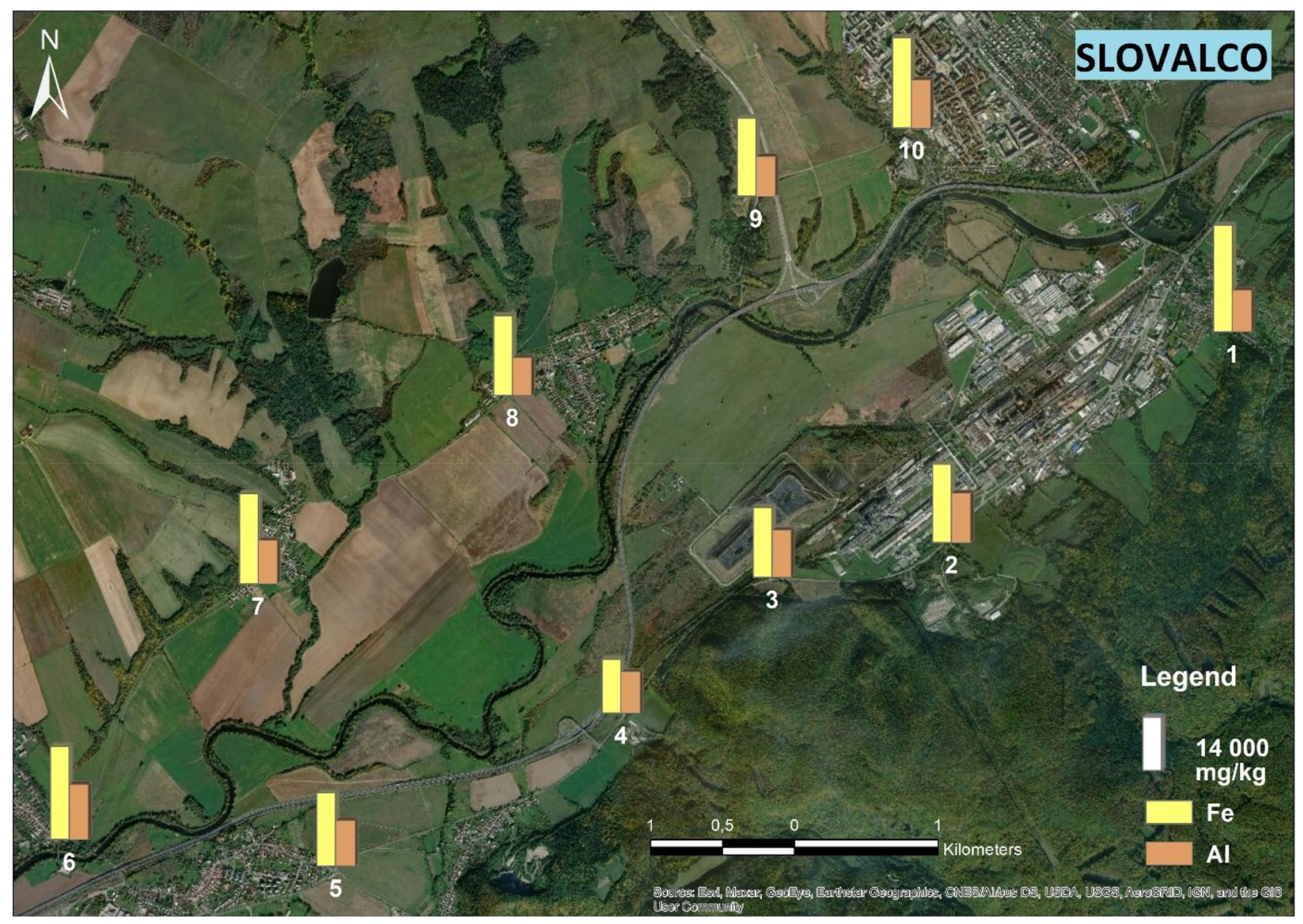

Fig. 7 Distribution of Al and Fe around SLOVALCO (Slovakia)

metals were observed even in residential sites, mostly in the case of Tajikistan and Slovakia; therefore, there is a high chance of transport pollutants and other industries located near the aluminium plants. Regarding these results, it can be concluded that the aluminium industry alone is the source of environmental pollution, and soils around these plants feature high concentrations of heavy metals. Moreover, information regarding past soil management in Tajikistan, and the related heavy metals input, was not known. Therefore, this study suggests more investigation in this area. 


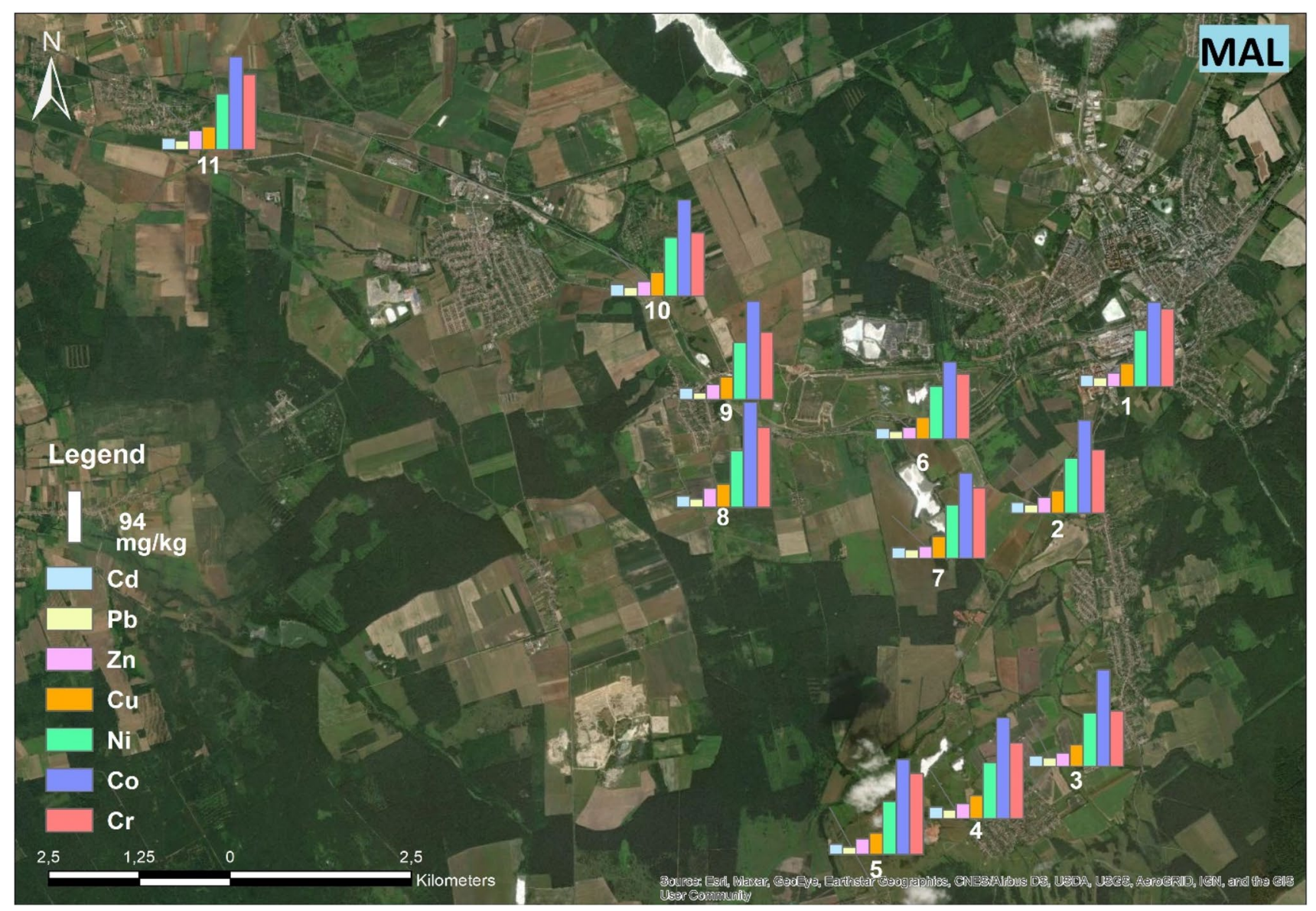

Fig. 8 Distribution of heavy metals around MAL (Hungary) 


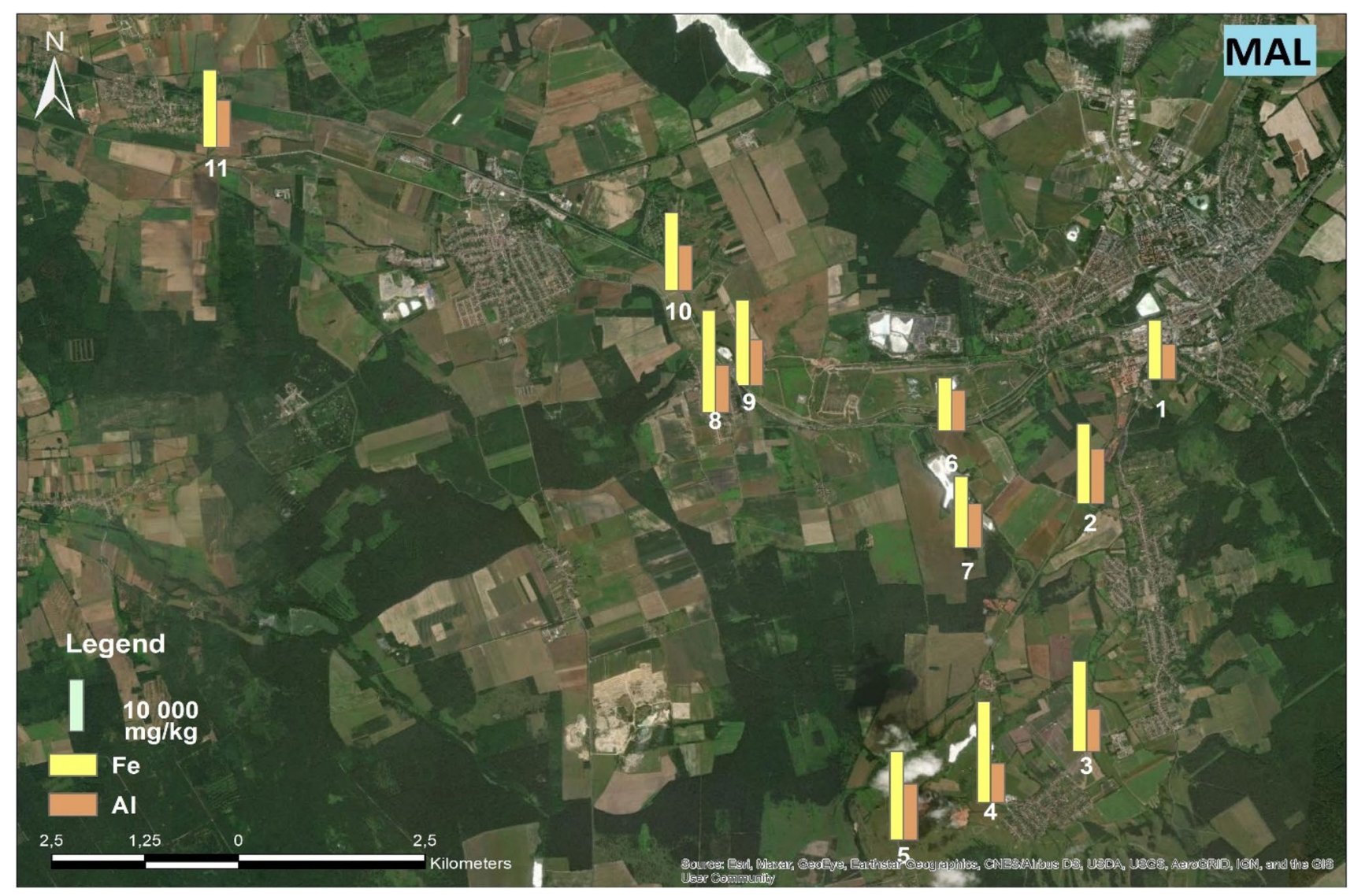

Fig. 9 Distribution of Al and Fe around MAL (Hungary)
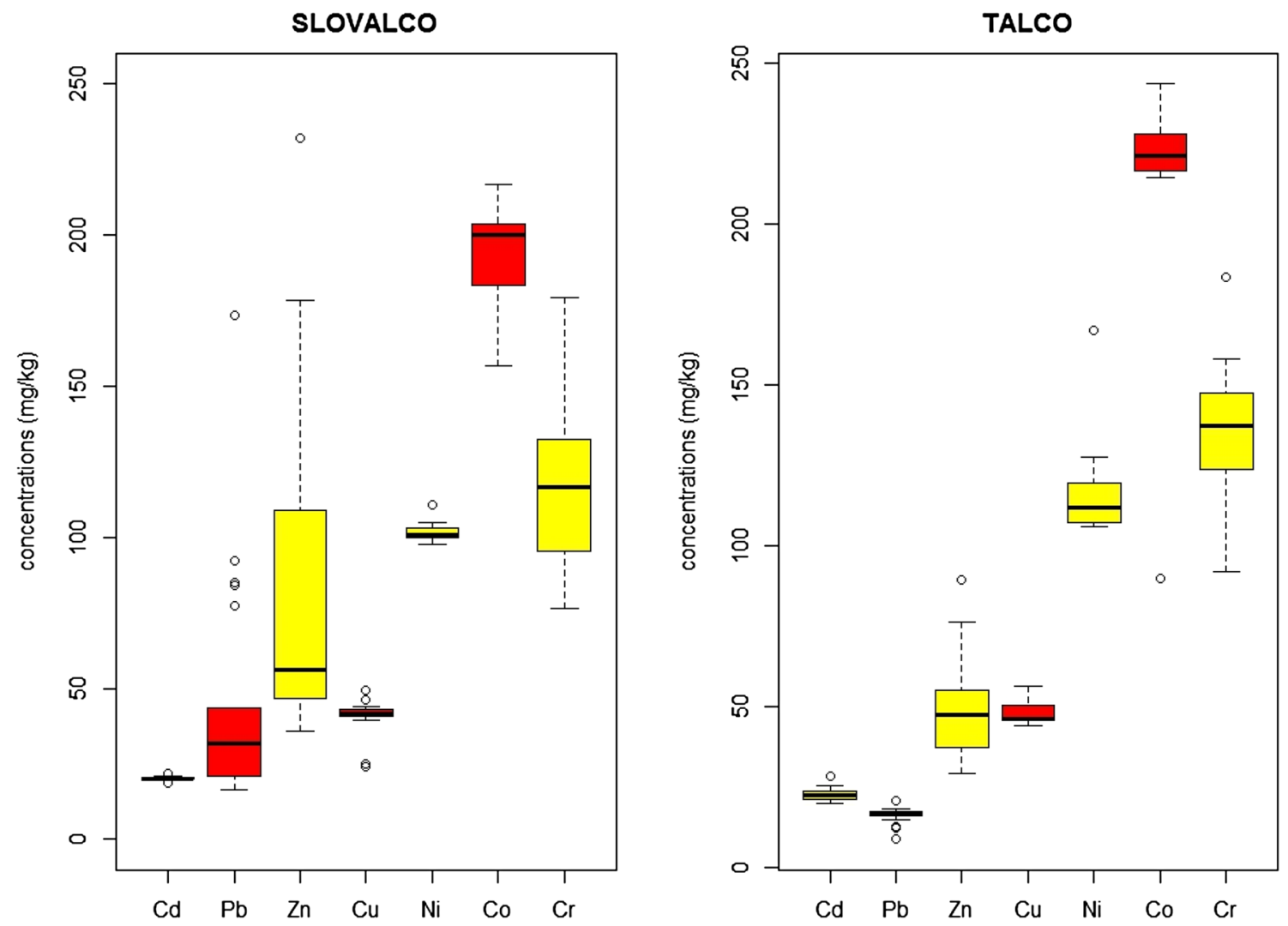

Fig. 10 Mean value concentrations of $\mathrm{Cd}, \mathrm{Pb}, \mathrm{Zn}, \mathrm{Cu}, \mathrm{Ni}, \mathrm{Co}$, and $\mathrm{Cr}$ in soil samples collected around aluminium plants (TALCO, SLOVALCO)

\section{SN Applied Sciences}


Fig. 11 Mean value concentrations of $\mathrm{Cd}, \mathrm{Pb}, \mathrm{Zn}, \mathrm{Cu}, \mathrm{Ni}$, $\mathrm{Co}, \mathrm{Cr}$ in soil samples around aluminium plants (MAL)

Fig. 12 Correlation coefficient matrix of metals in soil collected around TALCO
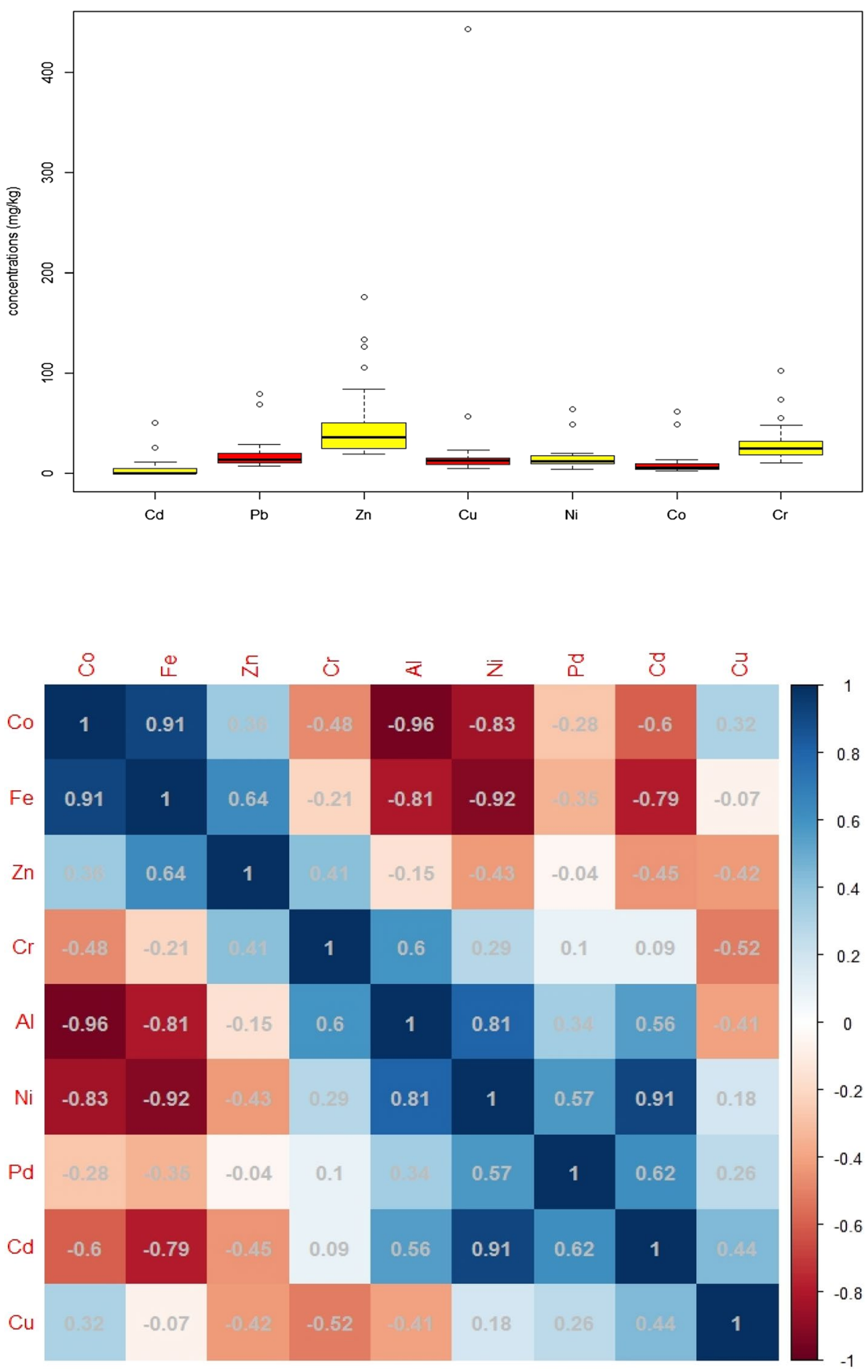
Fig. 13 Correlation coefficient matrix of metals in soil collected around SLOVALCO

Fig. 14 Correlation coefficient matrix of metals in soil collected around MAL
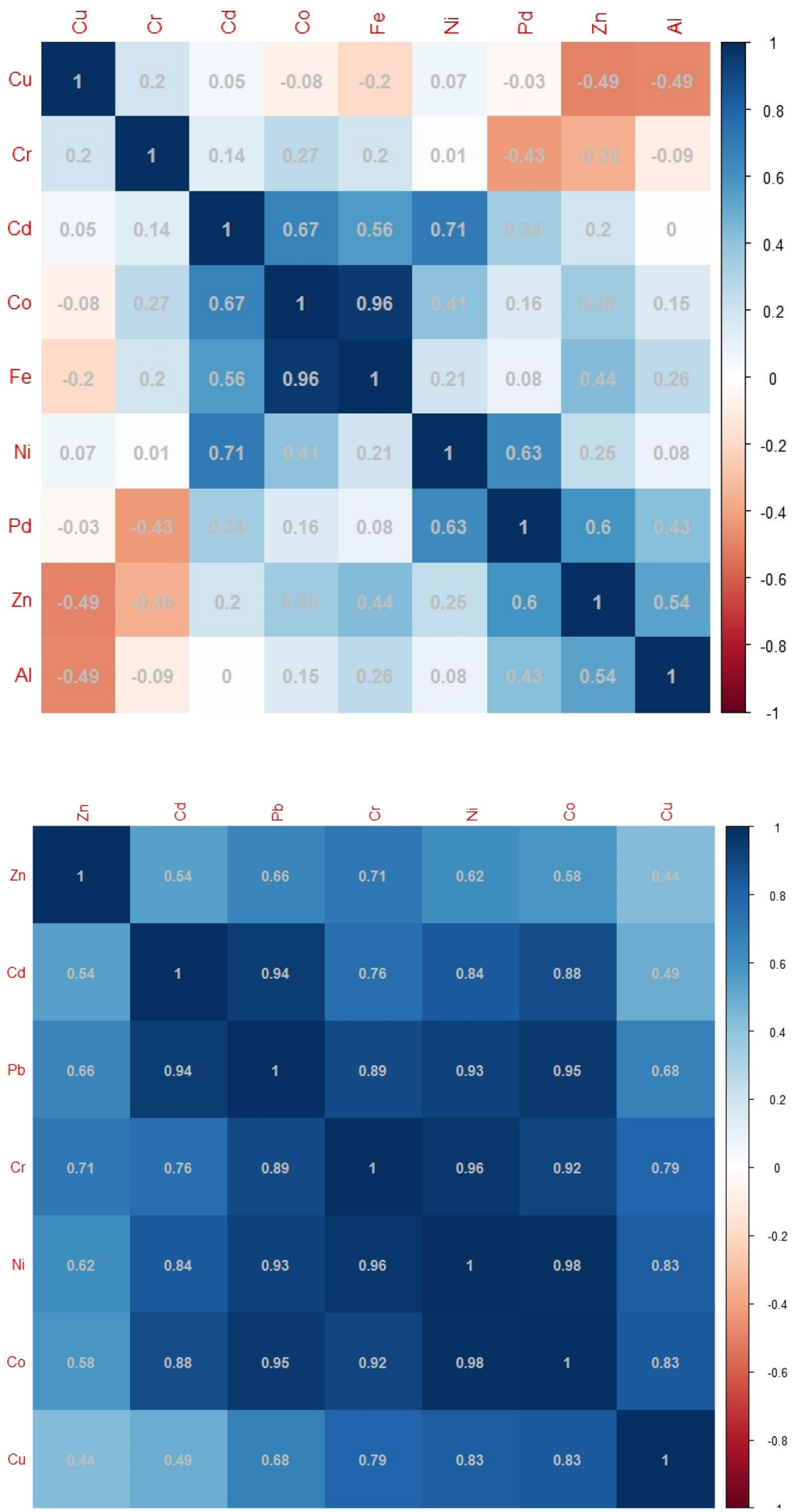
Funding This study was funded by Ministry of Education, Science, Research and Sport of the Slovak Republic.

\section{Compliance with ethical standards}

Conflict of interest The authors declare that they have no conflict of interest.

\section{References}

1. Chopra AK, Pathak C, Prasad G (2009) Scenario of heavy metal contamination in agricultural soil and its management. J Appl Nat Sci 1:99-108

2. Hu Y, Liu X, Bai J, Shih K, Zeng EY, Cheng H (2013) Assessing heavy metal pollution in the surface soils of a region that had undergone three decades of intense industrialization and urbanization. Environ Sci Pollut Res 20:6150-6159. https://doi. org/10.1007/s11356-013-1668-z

3. Klauber C, Gräfe M, Power G (2009) Review of bauxite residue "re-use" options. CSIRO Document DMR-3609, May 2009

4. Mora A, Pisapia D, González N, Handt H, Moreau C, Vásquez Y, Márquez L, Alfonso JA (2015) Impact of the red mud disposal on several floodplain lagoons of the lower Orinoco river. Water Air Soil Pollut 226(6):1-17

5. Feigl V, Anton A, Uzigner N, Gruiz K (2012) Red mud as a chemical stabilizer for soil contaminated with toxic metals. Water Air Soil Pollut 223:1237-1247. https://doi.org/10.1007/s1127 0-011-0940-4

6. Rotta LHS, Alcântara E, Park E, Negri RG, Lin YN, Bernardo N, Mendes TSG, Souza Filho CR (2020) The 2019 Brumadinho tailings dam collapse: Possible cause and impacts of the worst human and environmental disaster in Brazil. Int J Appl Earth Obs Geoinf 90(1):102119. https://doi.org/10.1016/j. jag.2020.102119

7. Winkler D, Bidló A, Bolodár-Varga B, Erdő A, Horváth A (2018) Long-term ecological effects of the red mud disaster in Hungary: regeneration of red mud flooded areas in a contaminated industrial region. Sci Total Environ 644:1292-1303. https://doi. org/10.1016/j.scitotenv.2018.07.059

8. Costa SC, Hartz SM (2009) Evaluation of trace metals (cadmium, chromium, copper and zinc) in tissues of a commercially important fish (Leporinus obtusidens) from Guaíba Lake. South Braz Braz Arch Biol Technol 52:241-250. https://doi.org/10.1590/ S1516-89132009000100029

9. Ali $\mathrm{H}$, Khan E, Ilahi I (2019) Environmental chemistry and ecotoxicology of hazardous heavy metals: environmental persistence, toxicity and bioaccumulation. J Chem 2019:6730305. https:// doi.org/10.1155/2019/6730305

10. Filep GY (1999) Soil contamination, soil remediation. In: Stefanovits P, Filep GY, Gy F (eds) Soil science. Publishing House of Agriculture, Budapest, pp 363-381
11. Xu L, Wu X, Zhou ZF (2016) Effects of physiological integration and fertilization on heavy metal remediation in soil by a clonal grass. Pol J Environ Stud 25:395-404. https://doi.org/10.15244/ pjoes $/ 60374$

12. State Unitary Enterprise TALCO, 2014. Research seminar presentation. Available at: https://talco.com.tj/en/sustainable-devel opment/presentations. 30.10.2020

13. Jamnická G, Bučinová K, Havranová I, Urban A (2007) Current state of mineral nutrition and risk elements in a beech ecosystem situated near the aluminium smelter in Žiar nad Hronom. Cent Slovakia Forest Ecol Manage 248:26-35. https://doi. org/10.1016/j.foreco.2007.02.033

14. Rékási M, Feigl V, Uzinger N, Gruiz K, Makó A, Anton A (2013) Effects of leaching from alkaline red mud on soil biota: modelling the conditions after the Hungarian red mud disaster. Chem Ecol 29:709-723. https://doi.org/10.1080/02757540.2013.81756

15. Anton A, Rékási M, Uzinger N, Széplábi G, Makó A (2012) Modelling the potential effects of the Hungarian red mud disaster on soil properties. Water Air Soil Pollut 223:5175-5188. https://doi. org/10.1007/s11270-012-1269-3

16. Winkler $D$ (2014) Collembolan response to red mud pollution in Western Hungary. Appl Soil Ecol 83:219-229. https://doi. org/10.1016/j.apsoil.2013.07.006

17. Birth $G$ (2003) A scheme for assessing human impacts on coastal aquatic environments using sediments. In: Woodcofie CD, Furness RA (eds) Coastal GIS, Wollongong University Papers in Center for Maritime Policy, Australia

18. Taylor SR (1964) Abundance of chemical elements in the continental crust: a new table. Geochim Cosmochim Acta 28:12731285. https://doi.org/10.1016/0016-7037(64)90129-2

19. Maximum allowable concentrations of chemical substances in soils, USSR State Committee for Nature, No 02-2333 from 10.12.90. Available at http://www.gidrogel.ru/ecol/hv_met. htm\#table2

20. Slovakia Act. No. 59 from 11 May 2013 on the protection and use of agricultural land. Ministry of Agriculture and Rural Development of the Slovak Republic. Available at http://www.zakon ypreludi.sk/zz/2013-59

21. Joint Decree. no.10/2000 (VI.2) (2000) KöM-EüM-FVM-KHVM of the ministers of environmental protection, public health, agriculture and regional development, and of traffic, communication and water management. Budapest

22. World Health Organisation, 2007. Health risks of heavy metals from long-range transboundary air pollution. Jt WHO I Conv Task Force Heal Asp Air Pollut. pp 2-144

23. Čurlík J, Šefčík P (1999) Geochemical atlas of the Slovak republik, part V: soils. Ministry of the Environment of the Slovak Republic, Soil Science and Conservation Research Institution, Bratislava

Publisher's Note pringer Nature remains neutral with regard to jurisdictional claims in published maps and institutional affiliations. 